\title{
ENVIRONMENTAL MANAGEMENT PROSPECTS OF INDUSTRIAL AREA: A CASE STUDY ON MCIE, INDONESIA
}

\author{
Sjaifuddin SJAIFUDDIN \\ Department of Science Education Universitas Sultan Ageng Tirtayasa, Serang Banten, Indonesia \\ E-mail: sjaifuddin@untirta.ac.id
}

Received 31 May 2018; accepted 08 October 2018

\begin{abstract}
In addition to promote economic growth, industrialization had caused negative impacts on the environment. It was required a lot of efforts to overcome negative impacts, although the results were still not as expected. Starting from this condition this research aimed to design an environmental management prospect of Modern Cikande Industrial Estate (MCIE) in Serang, Banten Province, Indonesia. Environmental management prospect designed using a prospective analysis. This technique used to explore various possibilities in the future in environmental management of MCIE based on eco-industrial parks (EIPs). The analysis showed that there were 5 (five) key factors determine the success of environmental management of MCIE: pollution control, investment security, availability of infrastructure, industrial tourism, and competitiveness of industry. The most implementable scenario in MCIE environmental management in the future was the new urbanism. This scenario oriented on the long term balance between economic growth and environmental protection.
\end{abstract}

Keywords: environmental management prospects, industrialization, prospective analysis, eco-industrial parks, key factors, new urbanism.

JEL Classification: O13, Q57.

\section{Introduction}

In the last decades, many regions all around the world were burdened with industrial pollution. In Europe, Austria was reportedly unable to suppress environmental degradation well even though policies to reduce environmental impacts had been implemented during the industrialization period (1830-1995) (Haberl and Krausmann 2001). In East Asia over the past decades, industry had developed very well; however, environmental degradation also unavoidable (Kim 2006). In many cities in Asia where industry was growing rapidly, increasing of $\mathrm{NO}_{2}$ always occurring. These could be found for example in the petrochemical complex at Jamnagar (India) and Daesan (Korea) (Duncan et al. 2015). In India, $\mathrm{SO}_{2}$ emissions are estimated to reach 7.8 million tons in 2010, since the year 2010 passed long ago. Although energy saving policies had been established, industry development was predicted contribute $\mathrm{SO}_{2}$ emissions to 26 million tons by 2040 (Heyes et al. 2015). In the perspective of health, high air pollution led to babies with low birth weight in China (Fleischer et al. 2014).

In the past, industry could build and take place anywhere. It then became a problem when control of the environmental impact must be carried out (Termsinvanich et al. 2013). While increased areas of land are required to sustain future development, land is a non-renewable natural resources and seemingly unlimited demand for the limited area available and caused increasingly serious problem (Wang et al. 2013). Integrated industrial management in an area became an alternative to overcoming the adverse impacts. Industrial area usually located in a semi artificial environment, functioning as a small town complete with a flow of information, materials and energy (Yang et al. 2012). According to Indonesian Government Regulation (UndangUndang Republik Indonesia Nomor 3 Tahun 2014), industrial park is the center of industrial activity, equipped with supporting facilities that are managed by a company licensed

Copyright (C) 2018 The Authors. Published by VGTU Press.

This is an Open Access article distributed under the terms of the Creative Commons Attribution License (http://creativecommons.org/licenses/by/4.0/), which permits unrestricted use, distribution, and reproduction in any medium, provided the original author and source are credited.. 
industrial area. Industrial areas built to enhance sustainable industrial development efforts, accelerate growth and competitiveness of industry and investment. In Indonesian cases, industrial parks tend to cluster in several locations. There were at least six suburban towns and sub-districts referred as industrial centers. Major industrial centers in Bodetabek (Bogor-Depok-Tangerang-Bekasi) (the outer suburbs) include Cikupa-Balaraja (Tangerang District) and Cikarang (Bekasi District). Four other industrial centers were located beyond Jabodetabek (Jakarta-Bogor-DepokTangerang-Bekasi) in the extra outer suburbs, which include Serang (Cilegon and Cikande) and Karawang (Teluk Jambe and Cikampek) (Hudalah et al. 2013).

Industrial areas managed environmentally were relevant to the idea of industrial ecology (McManus and Gibbs 2008). This idea stated that there was a potency to convert waste output into a resource input. Thus the cost of economic, social, and environment could be reduced, while the excess of utilization of raw materials could also be avoided. Efficiency improvements were the effective means of reducing resource consumption (Dahmus 2014). Eco-efficiency as a concept to allow for practical approach to economic and environmental efficiency based on sustainability, now has been suggested as a concept for improving corporate environmental and social performance (Suh et al. 2014)

In the policy level, the concept of industrial ecology was implemented through linkages among industrial companies that were in the same geographic area by establishing eco-industrial parks (EIPs). EIPs were the concrete applications of industrial ecology (IE) and industrial symbiosis (IS). Initially IE focused on the flow of matter and energy in an industrial system and less emphasized in policy mechanisms, but later this concept is complemented by IS, a tool used to foster eco-innovation and long-term cultural change (Daddi et al. 2015). IS should be an effective measure to balance the supply and demand of energy in a regional community (Kikuchi et al. 2015). EIPs in Shandong Province's Lubei in China and EIPs in Kalundborg Denmark had been recognized around the world as a successful example of EIPs. From the perspective of nodes, internal characteristics of industrial metabolic processes of EIPs in Shandong Province's Lubei in China were the key nodes (the cement clinker production), peripheral nodes (the ammonia and power plants), and key paths in the network (from the sulfuric acid plant to the ammonium phosphate plant to the cement clinker production (Zhang et al. 2015). EIPs in Kalundborg Denmark had reuse and recycling of resources to generate economic and environmental benefits. The symbiosis between local society and EPIs in Kalundborg had some advantages such as significant reduction in energy consumption, reduction in emission of sulfur dioxide $\left(\mathrm{SO}_{2}\right)$ and carbon dioxide $\left(\mathrm{CO}_{2}\right)$, also increasing transformation of conventional waste into raw feedstock in other processes (Zhao et al. 2017). Since its founding, EIPs in Kalundborg had managed to save more than 1.2 million $\mathrm{m}^{3}$ of water, and 30 thousand tons of fossil fuels. These EIPs also perform reuse of the 70,000 tons of fly ash and reduce more than 130,000 tons of $\mathrm{CO}_{2}$ emissions (Zhang et al. 2009). In South Korean EIPs pilot project, several projects involving energy networks produced a high positive environmental performance through greenhouse gas emissions mitigation. Waste acid/alkali solution recycling projects also showed remarkable social outcomes on account of the variety of networks formed and active participation from enterprises (Jung et al. 2013).

In Indonesia, the implementations of EIPs in industrial management had not widely known yet. Sona Maris Industry in Semarang, Indonesia is an example of EIPs (Tikhanov et al. 2016). However, in most Indonesian industrial estate, EIPs had not been implemented well, including in MCIE. MCIE is an industrial area located in Cikande, Serang District, Indonesia. As a center of new growth, MCIE equipped with infrastructure and complete supporting facilities. Currently, MCIE inhabited by more than 200 companies from various industries. From the description above, it was known that implementation of EIPs in MCIE was a necessity. The expected outcomes were certainly not just economic benefits, but also environmental balances in the long-term. This research objective was to design an MCIE environmental management prospect based on EIPs.

\section{Research methods}

MCIE environmental management based on EIPs is a process involving multi-stakeholders. The complexity of issues in MCIE required a holistic approach to solve the problem. This research was supported by data obtained through expert survey (Jones et al. 2013). A group of experts consisting of 8 experts of the industrial economy, 8 experts of environmental policy and management, and 4 experts of regional development conduct a discussion to identify factors determining the success of MCIE environmental management. Twenty (20) factors affecting the success of MCIE environmental management (FASM) were initially identified through a search of the relevant academic peerreviewed. This FASM list consisted of 8 factors relating to performance of management and productivity, 6 factors relating to functions of environmental protections, and 6 factors relating to economic and monetary policy. A preliminary expert panel was presented with the task to reduce this FASM list to more manageable factors. Experts evaluated each factor in term of its potency to determine the success of MCIE environmental management. The manageable factors were subsequently used to determine key factors in the prospective analysis (Table 1). 
The focused group is a scientific method in social sciences. The ultimate purpose of this methods is to discuss in depth on a certain issue to extract novel insights and expert knowledge, its usage and application in a highly values (May et al. 2016). To address the aim of research appropriately, Figure 1 illustrates a two steps research design approach.

Table 1. List of factors determining the success of MCIE environmental management

\begin{tabular}{|c|}
\hline \multicolumn{1}{|c|}{ Factors } \\
\hline Indicator: Performance of Management and Productivity \\
\hline 1. Competitiveness of industry \\
\hline 2. Industrial tourism \\
\hline 3. Contribution of industry \\
\hline Indicator: Functions of Environmental Protection \\
\hline 4. Pollution control \\
\hline 5. Community empowerment \\
\hline Indiator: Economic and Monetary Policy \\
\hline 6. Incentives of investment \\
\hline 7. Investment security \\
\hline 8. Consistency of policy \\
\hline 9. Availability of infrastructure \\
\hline
\end{tabular}

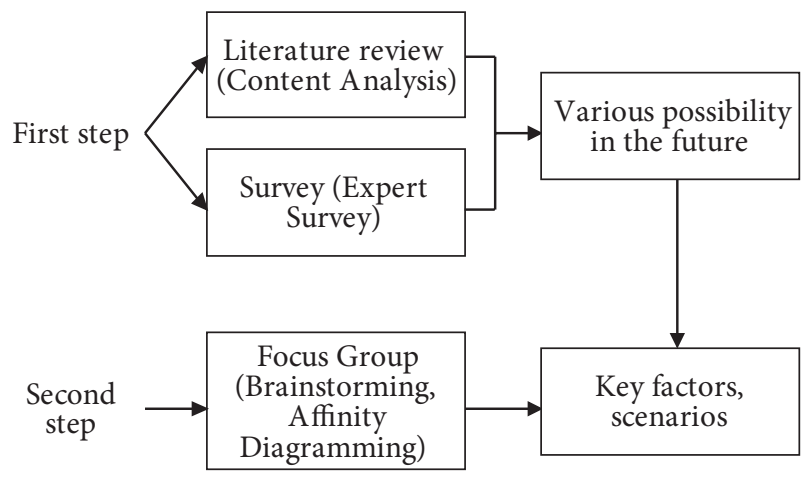

Figure 1. A two steps research design approach (May et al. 2016)

Table 2. The direct influence between factors in the MCIE environmental management system

\begin{tabular}{|c|c|c|c|c|c|c|c|}
\hline & A & B & C & D & E & F & G \\
\hline A & & & & & & & \\
\hline B & & & & & & & \\
\hline C & & & & & & & \\
\hline D & & & & & & & \\
\hline E & & & & & & & \\
\hline F & & & & & & & \\
\hline G & & & & & & & \\
\hline
\end{tabular}

Rating guidelines: score $0=$ no effect, score $1=$ small effect, score 2 = moderate effect, score 3 = very influential.
The data generated from expert survey was analyzed using prospective analysis. More than forecasts, prospective analysis views the distant future. It seeks to give shape to the next by introducing diverse scenarios involving different and imagined futures. Prospective analysis is the vision of the future that informs the choices to be made today, guiding decisions and actions. The main aim of prospective analysis is to illuminate the choice of the present by the possible futures (Godet 2007, Lapping et al. 2012). The stages in the prospective analysis as follows:

1. Determining the key factors to explore various possibilities in the future. At this stage, all factors were analyzed to know the effect of factors on system performance and factors interdependence as elements in the system. The rating of direct influence between factors in the system was done by using a scale of 0 to 3 as presented in Table 2 .

2. Determining the strategic objectives and interests of the main actors.

3. Defining and describing the various possibilities in the future.

Factors affecting the success of MCIE environmental management presented in a diagram (Figure 2). This figure showed four (4) quadrants illustrated below. Factors located in quadrant I and II did not affect the system performance, while the other ones located in quadrant III and IV would affect it.

\begin{tabular}{c|c} 
IV & III \\
\hline I & II
\end{tabular}

Figure 2. Factors affecting the system performance of MCIE environmental management

\section{Result and discussion}

\subsection{Description of study site}

MCIE was located in Cikande, Serang, Banten Province, Indonesia, approximately $68 \mathrm{~km}$ away from Jakarta, $75 \mathrm{~km}$ from Tanjung Priok Harbour and $50 \mathrm{~km}$ from SoekarnoHatta International Airport (Figure 3). MCIE could be accessed via Jakarta-Merak toll road within close proximity to Ciujung entrance toll. Nearby Bojonegara Seaport is now under development which will later become the Indonesia's largest export-import containers port. MCIE presents 3,175 ha of fully-serviced industrial zone with excellent quality infrastructures, best supporting facilities and well-planned estate management.

MCIE contained more than 200 of both local and foreign companies. It was home to a wide variety of industries 


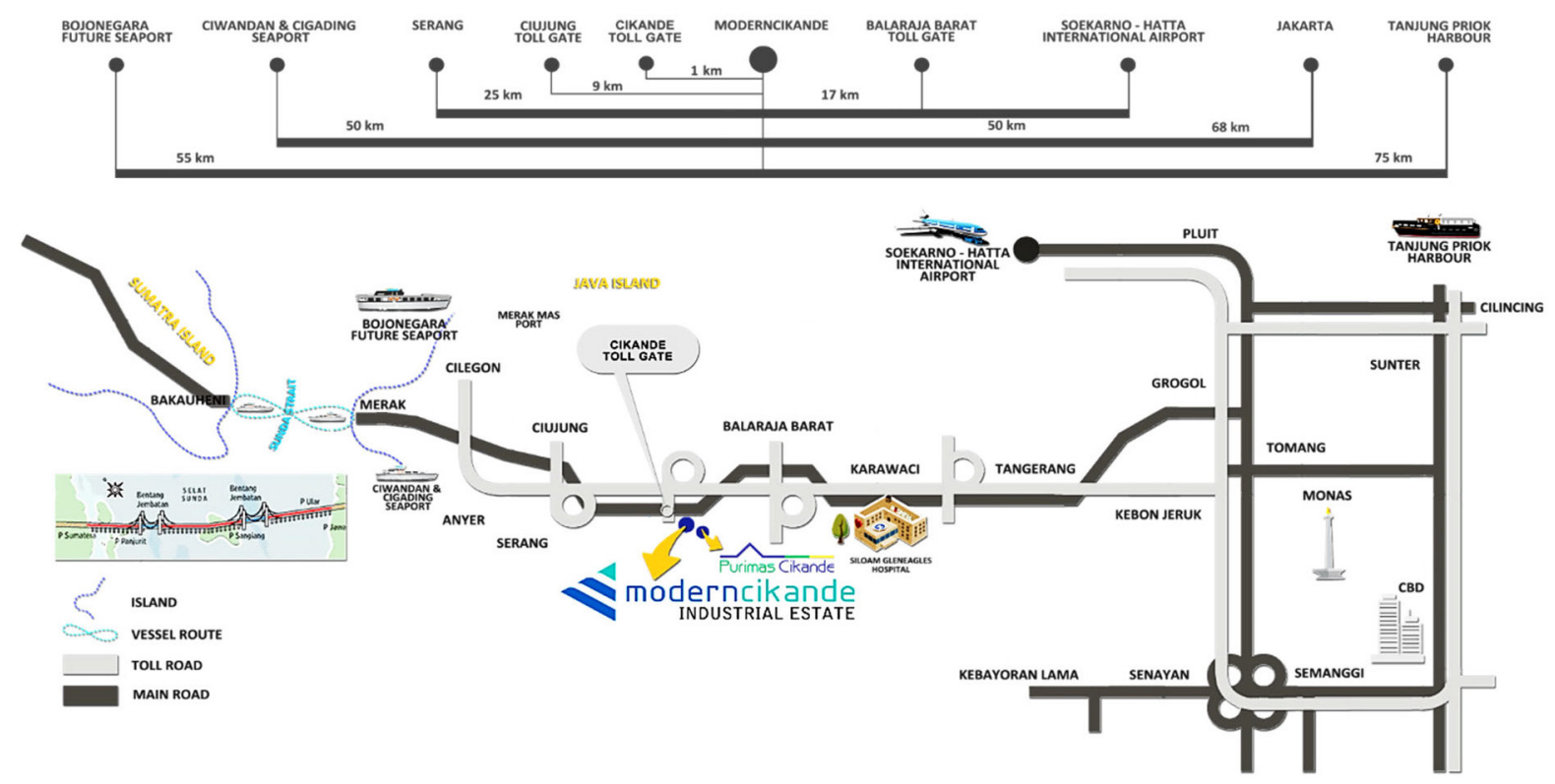

Figure 3. Map of the study site in Cikande, Serang, Banten Province, Indonesia

including chemical manufacturers, food processing manufacturers, automotive component producers, shoe components, and many more. Besides provided well-maintained infrastructures, MCIE also provided a one-stop service advising and assisting investors in all aspects of setting up their business in Indonesia. This included assisting the permit application and submission to the Indonesia Investment Coordinating Board (BKPM). An excellent quality of infrastructures collaborating with best supporting facilities, greenery landscape and well-planned estate management were MCIE's objectives in order to be one of the best industrial estates in western part of Jakarta.

\subsection{Key factors}

MCIE is a modern industrial system. There are many factors that influence the success of environmental management in a modern industrial system, both internal and external. Due to the limitations, this research identified 9 manageable factors that could be grouped into 3 main components. These 3 components were the performance of management and productivity, the functions of environmental protection, as well as the economic and monetary policy. The performance of management and productivity was the main component supported by 3 factors: competitiveness of industry, industrial tourism, and contribution of industry. The function of environmental protection was a major component supported by 2 factors: pollution control, and community empowerment. Economic and monetary policy was the main component that could be implemented through 4 factors: incentives of investment, investment security, consistency of policy and availability of infrastructure.
The following description presented 9 factors determining the success of MCIE environmental management in the future:

1. Competitiveness of industry

An indicator of competitive advantage is superior economic or market performance (Cerrato and Depperu 2011). The production cooperation is needed to improve the competitiveness of industry. Production cooperation is a system of economic relations among business entities to realize part or all of the production cycle in order to optimize costs and increase competitiveness (Fomina et al. 2018). MCIE had either competitive or comparative advantage to produce commodities that could to dominate the world market.

2. Industrial tourism

The opening of industrial locations to tourists encompasses a variety of perspectives (Hashimoto and Telfer 2016). Tourism based on industrial excellence provided minimized environmental impact in the MCIE zone and its surroundings. In the long term tourism will also provide sustainable and increasing economic growth (Kadriu 2016).

3. Contribution of industry Industrial cluster is a policy instrument used to improve regional innovation systems. The effect of industrial cluster on innovation activities depends on the type of industry. Industrial clusters have an important impact on increasing innovation in traditional industrial systems rather than high-tech industries (Žižka et al. 2018). Industrial restructuring were linked closely with environmental problems and economic development (Zhang et al. 2018). In this case, contribution of 
MCIE was studied in the relation to regional revenue, national income, and regional innovation system.

4. Pollution control

Essentially the most desirable actions are pollution prevention and waste minimization (Haridass et al. 2017); nevertheless pollution control is the other alternative. To reduce the negative environmental impact of energy production for example, it was recommended the implementation of modern technologies for reduction of raw material consumption and limits greenhouse gas emissions (Dzikuć and Piwowar 2015). Renewable energy could be used to reduce greenhouse gas emissions. The development of hydroelectric projects in Brazil was an example of efforts to use water resources as an alternative energy source (Rocha and Neves 2018). For the purpose of dilution, in releasing the effluent, the use of water bodies must consider the water quality class of the body. Changes caused by the effluent should not be so large as to change the class (Muniz et al. 2018).

5. Community empowerment

The involvement of local communities in various activities would improve social welfare and environmental protection in the MCIE and its surroundings (Ani et al. 2017). Community empowerment occurs when all members involved in each program for mutual benefit (Dzikuć and Piwowar 2015).

6. Incentives of investment

The stimulus provided by policy makers to the investors that willing to invest in the MCIE. Incentives make a role not only in the financial services industry, but also for all players in the securitization food chain (Murray et al. 2017).

7. Investment security

Government guarantees to the investors in the form of legislation that give protection and law enforcement in real investment security. Investment security can be illustrated as the need of an investment sector entities, the property of an investment system of the national economy, the policy of a state, the level of ability to attract investments, a factor of ensuring the economic security, an investment potential of the state, the level of socio-economic development of the state under the influence of investment inflows, and the control of recognized hazards to achieve an acceptable level of investment risk (as for investor, as for recipient) (Kharlamova 2014).

8. Consistency of policy

Guarantee to the creation of sustainable of investment over time and not affected by government intervention. Consistency of policies is a key factor to the firms' decision-making processes for reducing uncertainty because policy changes can cause risk-return perception for economic actors and also increase uncertainty (Yoon et al. 2017).

9. Availability of infrastructure

The infrastructures supported a wide range of industrial activities and for the local community. The infrastructures could include road networks, water supply, port/dock, education and health facilities and other facilities. Green infrastructure is an alternative approach for storm water management with co-benefits of temperature control, air quality management, wildlife habitat and amenity space (Chenoweth et al. 2018).

\subsection{The scenarios of environmental management}

An analysis of 9 factors determining the success of MCIE environmental management in the future produced 5 key factors (Figure 4). The key factors were factors that had a decisive influence on the performance of system, while the low dependence on other factors (more independent). Figure 4 showed that of the 9 factors, factors such as pollution control, investment security, availability of infrastructure, industrial tourism, and competitiveness of industry were 5 key factors determine the success of the environmental management of MCIE. The pollution control (1) was a key factor related to the function of environmental protection; while the investment security (2), availability of infrastructure (3), industrial tourism (4), and competitiveness of industry (5) related to the function of economic growth.

Each key factor had several possible future conditions. Based on the expert judgment, the possible future conditions of the pollution control were: no effort to control the pollution (1A), the pollution control had not done integrally and oriented on the sector interest (1B), the integrated pollution control was carried out across sectors and in ecological linkages (1C). The possible future conditions of the investment security were: the rule of law provided guarantees on the investment security (2A), the rule of law had not provided guarantees on the investment security (2B). The possible future conditions of the availability of infrastructure were: the infrastructures were built in line with the development planning phases (3A), the infrastructures were built but late due to various disturbances $(3 \mathrm{~B})$, the infrastructures were built unplanned (3C), the infrastructures were not built at all (3D). The possible future conditions of the industrial tourism were: the industrial tourism was planned across sectors and in ecological linkages (4A), the industrial tourism was not planned across-sector (4B), there is no effort to organize the industrial tourism absolutely $(4 \mathrm{C})$. The possible future conditions of the competitiveness of industry were: the industry had several comparative and competitive advantages (5A), the industry had one of the comparative 


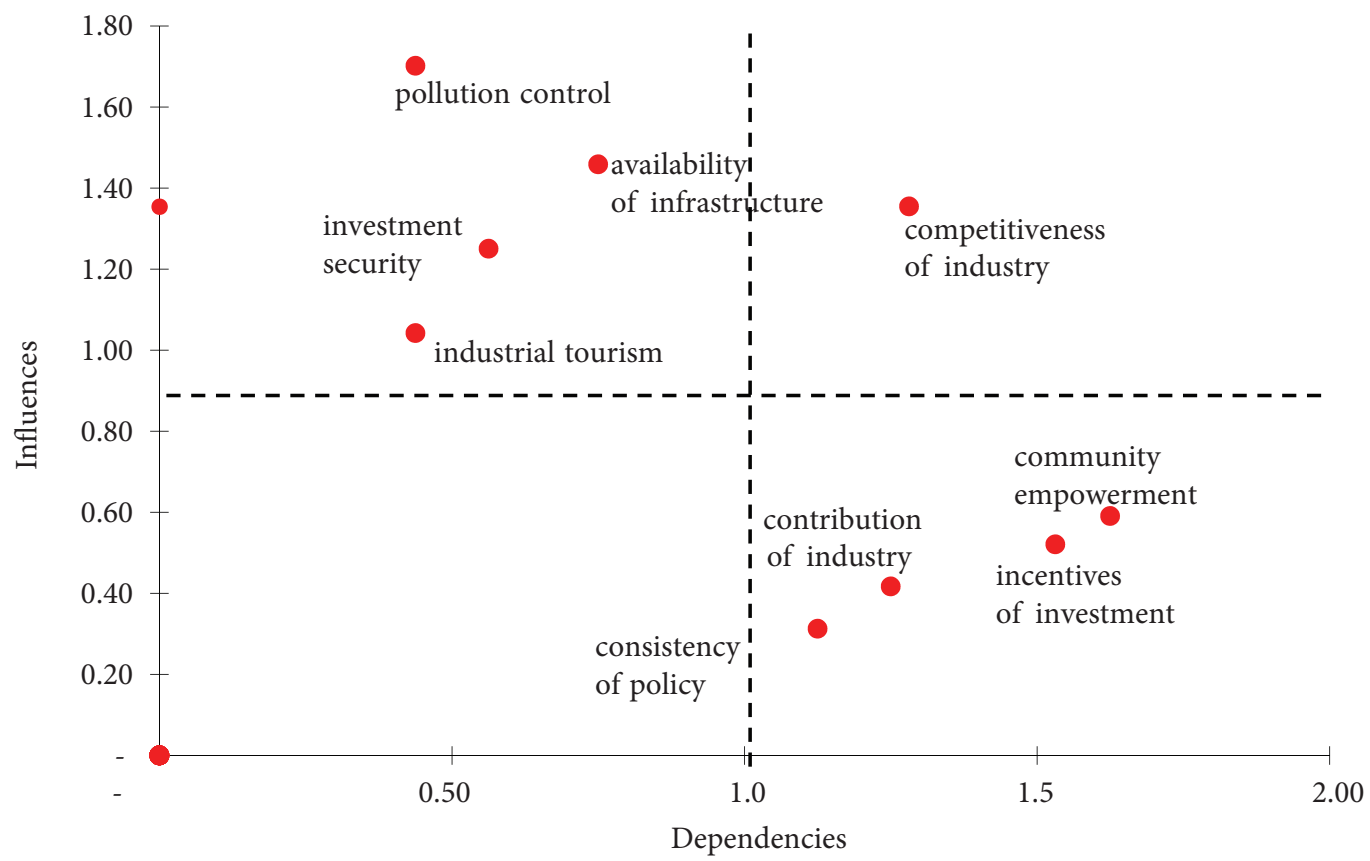

Figure 4. Factors determine the success of the environmental management of MCIE

or competitive advantages only (5B), the industry had no advantages at all (5C). These all possible future conditions of each key factor were then referred to as environmental management prospects and were presented in Table 3. These environmental management prospects then used to arrange the environmental management scenarios (Table 4). From Table 4, it was known that there were 3 environmental management scenarios of MCIE in the future. The following description presented the complete each scenario:

1. Conventional scenario (business as usual)

This scenario oriented on economic growth. Pollution control was not a major concern. This effort was often not done. Even if it was done, it was usually just for sector interest and not in integrated manner. To improve economic growth, investment security strictly enforced. The rule of law provided guarantees on investment security. To attract investors, infrastructures were built in line with the development planning phases. Cause of this scenario focused on the industrial sector, the tourism sector was not given enough attention so it was not planned across-sector. However, industrial sector well developed and it had several competitive and comparative advantages so as to control the world market.

2. Conservation scenario (conservationism) This scenario oriented on environmental protection. Pollution control became the main concern and it was carried out across sectors and ecological linkages. Because of its orientation on conservation, so, the security of investment was not guaranteed by the rule of law. High economic investment could weaken the functions of environmental protection. Infrastructures were built unplanned, or even totally not built. Good infrastructures would increase the passion of investments and ultimately could decrease the environmental protection. There was no management of industrial tourism because a welldeveloped industrial tourism would increase the number of tourists and could deteriorate the environmental protection. In this scenario, industrial competitiveness was also not a major concern, so the industry had no advantages at all.

3. New urbanism scenario

This scenario was a combination of two previous scenarios, oriented on the balance between economic growth and environmental protection. The pollution control became the main concern and be done with consideration of cross-sector and ecological linkages. Investment guarantees had been given in accordance to the rule of law. The infrastructures were built in line with the development planning phases. The industrial tourism was planned across sectors and in ecological linkages. The industrial sector encouraged to have comparative and competitive advantages to be able to control the world market.

From these 3 environmental management scenarios, it had been assessed on the possibility to be implemented in the future through expert judgment. An analysis of 3 scenarios presented in Figure 5 showed that new urbanism scenario $(70.00 \%)$ was in the first rank, followed by conservation scenario $(20.00 \%)$ in the second rank and the last rank was conventional scenario (business as usual) 
Table 4. Environmental management scenarios of MCIE in the future

\begin{tabular}{|l|l|}
\hline \multicolumn{1}{|c|}{ Scenarios } & \multicolumn{1}{c|}{ Sequence of Factor } \\
\hline Conventional (business as usual) & 1A/B-2A-3A-4B/C-5A \\
\hline Conservation (conservationism) & 1C-2B-3C/D-4C-5C \\
\hline New urbanism & 1C-2A-3A-4A-5A \\
\hline
\end{tabular}

(10.00\%). These results also indicated that new urbanism was the most implementable scenario in MCIE environmental management in the future. New urbanism promotes mixed use and high design standards. Good design can build social cohesion and social capital and recognize significant contribution to designing environments intended to enhance urban quality of life (Grant 2015).

\section{Conclusions}

There were 5 key factors that had a decisive influence on the MCIE environmental management such as pollution control, investment security, availability of infrastructure, industrial tourism, and competitiveness of industry. There was a scenario called new urbanism that had a high possibility to be implemented in the future. This scenario oriented on the long term balance between economic growth and environmental protection. According to an economic perspective, the well-built infrastructures and high investment securities would attract more investment. A competitive industry would produce commodities that

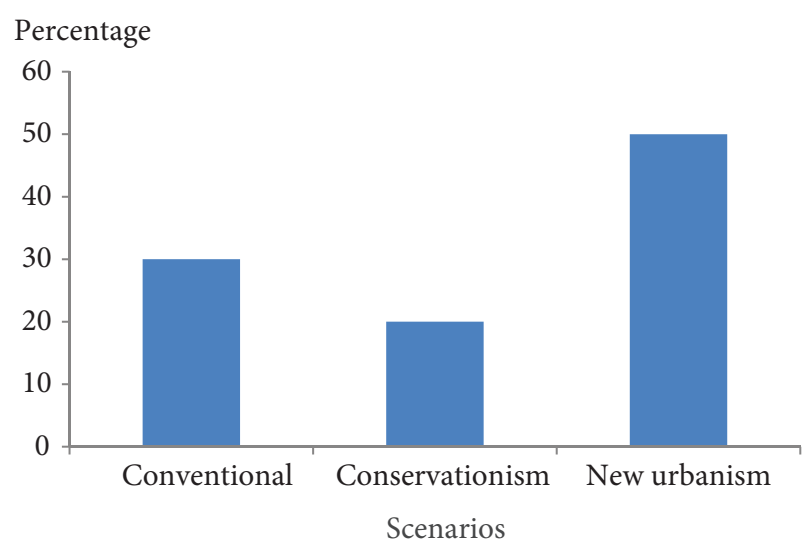

Figure 5. Expert judgment on the three scenarios

could dominate the world market. A competitive industry would also open a new opportunity for the creation of industrial tourism that has a high added value. According to an environmental protection perspective, the utilization of modern technology could reduce the use of raw materials and greenhouse gas emissions.

\section{Acknowledgements}

I am thankful to Directorate General of Research and Community Service, Ministry of Research, Technology, and Higher Education, Republic of Indonesia that had funded this research.

Table 3. Environmental management prospects of MCIE in the future (year 2030)

\begin{tabular}{|c|c|c|c|c|}
\hline \multirow[b]{2}{*}{ FACTORS } & \multicolumn{4}{|c|}{ CONDITIONS } \\
\hline & $1 \mathrm{~A}$ & $1 \mathrm{~B}$ & $1 \mathrm{C}$ & \\
\hline \multirow[t]{2}{*}{ Pollution control } & $\begin{array}{l}\text { No effort to control the pollu- } \\
\text { tion }\end{array}$ & $\begin{array}{l}\text { The pollution control had not } \\
\text { done integrally and oriented on } \\
\text { the sector interest }\end{array}$ & $\begin{array}{l}\text { The integrated pollution } \\
\text { control was carried out } \\
\text { across sectors and in eco- } \\
\text { logical linkages }\end{array}$ & \\
\hline & $2 \mathrm{~A}$ & $2 \mathrm{~B}$ & & \\
\hline \multirow[t]{2}{*}{$\begin{array}{l}\text { Investment } \\
\text { security }\end{array}$} & $\begin{array}{l}\text { The rule of law provided gua- } \\
\text { rantees on investment } \\
\text { security }\end{array}$ & $\begin{array}{l}\text { The rule of law had not provi- } \\
\text { ded guarantees on investment } \\
\text { security }\end{array}$ & & \\
\hline & $3 \mathrm{~A}$ & $3 \mathrm{~B}$ & $3 \mathrm{C}$ & $3 \mathrm{D}$ \\
\hline \multirow[t]{2}{*}{$\begin{array}{l}\text { Availability of } \\
\text { infrastructure }\end{array}$} & $\begin{array}{l}\text { The infrastructures were built } \\
\text { in line with the development } \\
\text { planning phases }\end{array}$ & $\begin{array}{l}\text { The infrastructures were built } \\
\text { but late due to various distur- } \\
\text { bances }\end{array}$ & $\begin{array}{l}\text { The infrastructures were } \\
\text { built unplanned }\end{array}$ & $\begin{array}{l}\text { The infrastructu- } \\
\text { res were not built } \\
\text { at all }\end{array}$ \\
\hline & $4 \mathrm{~A}$ & $4 \mathrm{~B}$ & $4 \mathrm{C}$ & \\
\hline \multirow[t]{2}{*}{$\begin{array}{l}\text { Industrial tou- } \\
\text { rism }\end{array}$} & $\begin{array}{l}\text { The industrial tourism was } \\
\text { planned across sectors and in } \\
\text { ecological linkages }\end{array}$ & $\begin{array}{l}\text { The industrial tourism was not } \\
\text { planned across-sector }\end{array}$ & $\begin{array}{l}\text { There is no effort to orga- } \\
\text { nize the industrial tourism } \\
\text { absolutely }\end{array}$ & \\
\hline & $5 \mathrm{~A}$ & $5 \mathrm{~B}$ & $5 \mathrm{C}$ & \\
\hline $\begin{array}{l}\text { Competitiveness } \\
\text { of industry }\end{array}$ & $\begin{array}{l}\text { The industry had several } \\
\text { comparative and competitive } \\
\text { advantages }\end{array}$ & $\begin{array}{l}\text { The industry had one of the } \\
\text { comparative or competitive } \\
\text { advantages only }\end{array}$ & $\begin{array}{l}\text { The industry had no } \\
\text { advantages at all }\end{array}$ & \\
\hline
\end{tabular}




\section{References}

Ani F, Ramlan N, Jaes L, Damin A, Halim H, Khadijah S, Abu S, Ahmad S (2017) Applying empowerment approach in community development. In: Proceeding the $1^{\text {st }}$ International Conference on Social Sciences, Universitas Muhammadiyah, Jakarta (Indonesia).

Cerrato D, Depperu D (2011) Unbundling the construct of firm-level international competitiveness. The Multinational Business Review 19 (4): 311-331. https://doi.org/10.1108/ 15253831111190162

Chenoweth J, Anderson AR, Kumar P, Hunt WF, Jane S Moore TLC (2018) The interrelationship of green infrastructure and natural capital. Land Use Policy 75: 137-144. https://doi.org/ 10.1016/j.landusepol.2018.03.021

Dahmus J B (2014) Can efficiency improvements reduce resource consumption? Journal of Industrial Ecology 18 (6): 883-897. https://doi.org/10.1111/jiec.12110

Daddi T, Iraldo F, Frey M, Gallo P, Gianfrate V (2015) Regional policies and eco-industrial development: the voluntary environmental certification scheme of the eco-industrial parks in Tuscany (Italy). Journal of Cleaner Production 114: 62-70. https://doi.org/10.1016/j.jclepro.2015.04.060

Duncan BN, Lamsal LN, Thompson AM, Yoshida Y, Lu Z, Streets DG, Hurwitz MM, Pickering KE (2015) A space-based, high-resolution view of notable changes in urban $\mathrm{NO}_{\mathrm{x}}$ pollution around the world (2005-2014). Journal of Geophysical Research: Atmospheres 121 (2): 976-996. https://doi. org/10.1002/2015JD024121

Dzikuć M, Piwowar A (2015) Life cycle assessment as an ecomanagement tool within the power industry. Polish Journal of Environmental Stdies 24 (6): 2381-2385. https://doi.org/ $10.15244 /$ pjoes/58889

Fleischer NL, Merialdi M, Donkelaar A, Vadillo-ortega F, Martin RV (2014) Outdoor air pollution, preterm birth, and low birth weight: analysis of the world health organization global survey on maternal and perinatal health. Environmental Health Perspectives 122 (4): 425-430. https://doi.org/10.1289/ehp.1306837

Fomina AV, Berduygina ON, Shatsky AA (2018) Industrial cooperation and its influence on sustainable economic growth. Entrepreneurship and Sustainability Issues 5 (3): 467-479. https://doi.org/10.9770/jesi.2018.5.3(4)

Godet M (2007) Effective strategic management the prospective approach. Technology Analysis \& Strategic Management 1 (1): 45-56. https://doi.org/10.1080/09537328908523954

Grant JL (2015) New urbanism. International Encyclopedia of the Social \& Behavioral Sciences (2nd ed). Elsevier.

Haberl H, Krausmann F (2001) Changes in population, affluence, and environmental pressures during industrialization: the case of Austria 1830-1995. Population and Environment 23 (1): 49-70. https://doi.org/10.1023/A:1017512325580

Haridass R, Ramesh K, Rajeshkumar T, Vignesh E (2017) Performance improvement of pollution control device used in small scale foundry industry. International Journal of Research in Science and Engineering 3 (1). https://doi.org/10.15244/ pjoes/58889

Hashimoto A, Telfer DJ (2016) Transformation of Gunkanjima (Battleship Island): from a coalmine island to a modern industrial heritage tourism site in Japan. Journal of
Heritage Tourism 6631: 1-18. https://doi.org/10.1080/17438 73X.2016.1151884

Heyes C, Kiesewetter G, Klimont Z, Purohit P, Rafaj P, Sander R, Schöpp W, Amann M (2015) Implications of energy trajectories from the World Energy Outlook 2015 for India's air pollution. Final Report. International Institute for Applied System Analysis, 14 April 2015.

Hudalah D, Viantari D, Firman T, Woltjer J (2013) Industrial land development and manufacturing deconcentration in Greater Jakarta. Urban Geography 34 (7): 950-971. https://doi.org/10 $.1080 / 02723638.2013 .783281$

Jones AK, Jones DL, Edwards-Jones G, Cross P (2013) Informing decision making in agricultural greenhouse gas mitigation policy: a best-worst scaling survey of expert and farmer opinion in the sheep industry. Environmental Science and Policy 29: 46-56. https://doi.org/10.1016/j.envsci.2013.02.003

Jung S, Dodbiba G, Chae SH, Fujita T (2013) A novel approach for evaluating the performance of eco-industrial park pilot projects. Journal of Cleaner Production 39: 50-59. https://doi. org/10.1016/j.jclepro.2012.08.030

Kadriu A (2016) Tourism development and its impact on the overall economic and environmental development of the country. Journal of Environmental Protection and Ecology 17 (1): 268-275.

Kikuchi Y, Kanematsu Y, Ugo M, Hamada Y, Okubo T (2015) Industrial symbiosis centered on a regional cogeneration power plant utilizing available local resources. Journal of Industrial Ecology 20 (2): 276-288. https://doi.org/10.1111/jiec.12347

Kim JW (2006) The environmental impact of industrialization in East Asia and strategies toward sustainable development. Sustainability Science 1 (1): 107-114. https://doi.org/10.1007/ s11625-006-0006-5

Kharlamova G (2014) Investment security of industries: rating assessment (case of Ukraine). Procedia Economics and Finance 16: 657-668. https://doi.org/10.1016/S2212-5671(14)00854-5

Lapping K, Frongillo EA, Studdert LJ, Menon P, Coates J, Webb P (2012) Prospective analysis of the development of the national nutrition agenda in Vietnam from 2006 to 2008. Health Policy and Planning 2012 (27): 32-41. https://doi.org/10.1093/ heapol/czr013

May G, Stahl B, Taisch M (2016) Energy management in manufacturing: toward eco-factories of the future-a focus group study. Applied Energy 164: 628-638. https://doi.org/10.1016/j. apenergy.2015.11.044

McManus P, Gibbs D (2008) Industrial ecosystems ? The use of tropes in the literature of industrial ecology and eco-industrial parks. Progress in Human Geography 32 (4): 525-540. https:// doi.org/10.1177/0309132507088118

Murray N, Manrai AK, Manrai LA (2017) The financial services industry and society financial crisis. Journal of Economics, Finance and Administrative Science 22 (43): 168-190. https:// doi.org/10.1108/JEFAS-02-2017-0027

Muniz J, da Gloria M, de Melo G, Liberato MAR, Wahnfried I, Vieira G (2018) Towards sustainability: allowance rights for using water resources in Amazonas State of Brazil. Entrepreneurship and Sustainability Issues 5 (4): 761-771. https://doi. org/10.9770/jesi.2018.5.4(6)

Rocha GM, Neves MB (2018) Hydroelectric projects and territorial governance in regions of The State of Pará, Brazilian 
Amazon. Entrepreneurship and Sustainability Issues 5 (4): 712-723. https://doi.org/10.9770/jesi.2018.5.4(1)

Suh Y, Seol H, Bae H, Park Y (2014) Eco-efficiency based on social performance and its relationship with financial performance. Journal of Industrial Ecology 18 (6): 909-919. https://doi. org/10.1111/jiec. 12167

Termsinvanich P, Thadaniti S, Wiwattanadate D (2013) Conceptual model for effective implementation of industrial symbiosis: a case study of Mab-Ta-Phut industrial estate. Mediterranean Journal of Social Sciences 4 (1): 133-139.

Tikhanov E, Krivorotov V, Kalina A, Erypalov S (2016) Model of eco-industrial park development as a tool for fostering energy efficient economy. E3S Web of Conferences 6, 03005.

Wang H, Shen Q, Tang BS, Skitmore M (2013) An integrated approach to supporting land-use decisions in site redevelopment for urban renewal in Hong Kong. Habitat International 38 (1): 70-80. https://doi.org/10.1016/j.habitatint.2012.09.006

Yang J, Chen B, Qi J, Zhou S, Jiang M (2012) Life-cycle-based multicriteria sustainability evaluation of industrial parks: a case study in China. The Scientific World Journal 2012: 9. https://doi.org/10.1100/2012/917830

Yoon J, Oh Y, Lee J (2017) The impact of policy consistency on technological competitiveness: a study on OECD countries. Energy Policy 108: 425-434. https://doi.org/10.1016/j.enpol.2017.06.013
Zhang Y, Zheng H, Yang Z, Liu G, Su M (2015) Analysis of the industrial metabolic processes for sulfur in the Lubei (Shandong Province, China) eco-industrial park. Journal of Cleaner Production, 127-138. https://doi.org/10.1016/j. jclepro.2014.01.096

Zhang J, Jiang H, Liu G, Zeng W (2018) A study on the contribution of industrial restructuring to reduction of carbon emissions in China during the five Five-Year plan periods. Journal of Cleaner Production 176: 629-635. https://doi. org/10.1016/j.jclepro.2017.12.133

Zhang H, Hara K, Yabar H, Yamaguchi Y, Uwasu M, Morioka, T (2009) Comparative analysis of socio-economic and environmental performances for Chinese EIPs: case studies in Baotou, Suzhou, and Shanghai. Sustainability Science 4 (2): 263-279. https://doi.org/10.1007/s11625-009-0078-0

Zhao H, Zhao H, Guo S (2017) Evaluating the comprehensive benefit of eco-industrial parks by employing multi-criteria decision making approach for circular economy. Journal of Cleaner Production 142: 2262-2276. https://doi.org/10.1016/j. jclepro.2016.11.041

Žižka M, Hovorková Valentová V, Pelloneová N, Štichhauerová E (2018) The effect of clusters on the innovation performance of enterprises: traditional vs new industries. Entrepreneurship and Sustainability Issues 5 (4): 780-794. https://doi.org/ 10.9770/jesi.2018.5.4(6) 